\title{
ARTICLE
}

\section{Time and Law in the Post-COVID-19 Era: The Usefulness of Experimental Law}

\author{
Special Issue Experimental Legislation in Times of Crisis, \\ Sofia Ranchordas \& Bart van Klink (eds.)
}

Erik Longo*

\begin{abstract}
The COVID-19 pandemic swept the world in 2020 impelling us to reconsider the basic principles of constitutional law like the separation of power, the rule of law, human rights protection, etc. The two most pressing legal issues that have attracted the attention of legal scholars so far are, on the one hand, the different regulatory policies implemented by governments and, on the other, the balance among the branches of government in deciding matters of the emergency. The pandemic has determined a further and violent acceleration of the legislature's temporal dimension and the acknowledgement that, to make legislation quicker, parliament must permanently displace its legislative power in favour of government. Measures adopted to tackle the outbreak and recover from the interruption of economic and industrial businesses powerfully confirm that today our societies are more dependent on the executives than on parliaments and, from a temporal perspective, that the language of the law is substantially the present instead of the future. Against this background, this article discusses how the prevalence of governments' legislative power leads to the use of temporary and experimental legislation in a time, like the pandemic, when the issue of 'surviving' becomes dominant.
\end{abstract}

Keywords: COVID-19, time and law, law-making, parliament, government, legal certainty.

El tiempo es la sustancia de que estoy hecho.

El tiempo es un río que me arrebata, pero yo soy el río;

es un tigre que me destroza, pero yo soy el tigre;

es un fuego que me consume, pero yo soy el fuego (Borges, 1960)

* Prof. Dr. Erik Longo is associate professor of Constitutional Law at the University of Florence. 


\section{Introduction}

The impact of COVID-19 on European countries resembles the description of a 'perfect storm', when the effects of an event overwhelm the combinations of single circumstances. Responding to the pandemic has involved a new regulatory burden at nearly every stage.

In order to combat the pandemic, many states have triggered temporary healthcare and prophylaxis measures, imposed quarantines and limited freedom of circulation, organized smart working, and implemented curfews and lockdowns that have led to painful economic consequences. In an ongoing crisis where much of the evidence is not complete, and information is evolving rapidly, it becomes incredibly challenging to issue a regulation that is not destined to be changed quickly as the pandemic moves forward.

COVID-19 legislation has a task that no other emergency measure has had before (Pistor, 2020). The two most pressing legal issues that have attracted the attention of legal scholars so far are, on the one hand, the different regulatory policies by governments and, on the other, the balance among the branches of government in deciding matters of the emergency (Alemanno, 2020; Ginsburg \& Versteeg, 2020; Popelier, 2020). Data show that governments have been under intense pressure to develop rapid policy responses to the pandemic and have used summarized legislative procedures and new forms of emergency committees to urgently pass a range of crisis-related regulations (Griglio, 2020; OECD, 2020).

From our perspective, measures adopted to tackle the outbreak and recover from the interruption of economic and industrial businesses powerfully confirm our constitutional Zeitgeist (the supreme spirit of our constitutional experience of time): our constitutional systems are more dependent on the work of the executives than on that of parliaments (Barber, 2018; Loughlin, 2019; Tsebelis, 2009) and, from a temporal perspective, the language of the law is dominantly the present instead of the future (Husserl, 1955). The pandemic has determined a further and violent recognition that, to speed up legislation, parliaments must permanently displace their legislative power in favour of governments. This new constitutional leap has completed Carl Schmitt's old prophecy of the executives' motorized legislature - as he masterfully explained in several conferences on the end of the second world conflict (Schmitt, 1950).

'Motorized legislation' issued by governments possesses the double advantage of being, on the one hand, dynamic (as opposed to relatively static forms of legislation) and, on the other, able to provide an easily changeable framework for social and economic activity (Longo, 2017). Democratic decision making and interest mediation are time-consuming. The will of the legislature tends to be slow-going and not well equipped to keep pace with continually changing societies since political commitments also tend to become short-lived. As a result, it is becoming increasingly arduous for parliaments to be on time and to effectively govern the present (identifying, formulating and representing collective interests) by using law-making.

The prevalence of governments' legislative power does not indicate the decay of liberal constitutionalism per se, but only a transformation of it (Teubner, 2012; 
Weinrib, 2006). Parliaments are less competent, and parliamentary procedures not well suited for regulating new relationships (Scheuerman, 2002). Hence, we need a new reflection on the specific 'constitutional dimension of time', one that puts accelerated time definitively into the realm of the executives and opens up new forms of assuming time dimension in law-making.

As is argued in Section 3, a new kind of legal representation of time is dawning in the pandemic era. To cite Canetti (1981), I call it 'survivor time' since it represents the condition of everybody living in the same terrible state of waiting and distancing. Contagion, which in any pandemic is crucial, makes it possible to isolate men and women. The best way to survive is to wait and stay at a safe distance from others or separate oneself completely. The perspective on living and life itself consists of avoiding death by being distant from the sick and likely sick. This situation extends from individuals to institutions: our life is organized around the necessity to survive in a risky society.

Therefore, the pandemic marks the turning point for further consideration of time and law, the use of the 'precautionary' principle, the justification for 'evidence-based' legislation (Meßerschmidt, 2020), and, last but not least, the permanent issue of the 'crisis of legislation'.

Against this background, the approach in this article is mostly theoretical and applicable to all continental legal systems, though most examples come from Italy. The article proceeds as follows. In Section 2, I briefly sketch out some of the essential elements of the relationship between law and time. I pick out the theoretical scheme of Gerhard Husserl and the reflections of some European jurists for their relevance in the investigation of time from a legal perspective. In Section 3, I gauge the importance of the three dimensions of experienced time in law-making. In Section 4, I analyse the influence of accelerated time on law-making and temporary legislation issues in this new era, which marks a definitive detachment from the Enlightenment intrinsic idea of the rationality of law. My final aim is to study the new temporal dimension of law in the post-COVID-19 world.

In this article, I use the term legislation in a broad sense (Wintgens, 2002). It means not only statute law and parliamentary legislation, but also government's delegated and emergency legislation. The term may be read also as covering all measures encompassing the enactment of general rules at the constitutional level and in international law.

\section{Law and Time in the Perspective of Legal Transformation}

\subsection{Law in Time and Time in Law}

As a product of human thought, the law implies temporality (French, 2001; Nousiainen, 1995; Posner, 2017). Law is, indeed, a particular 'technique of temporal manipulation' (Frosini, 1999, p. 432).

However, these statements do not resolve the way in which we intend the link between law and time. Some legal scholars propose a summa divisio for this relationship, considering, on the one hand, issues of law in time and, on the other, those of time in law (Mengoni, 1998). The first is one of the most entangled ontological problems of law because it implies the meaning, effectiveness and existence 
of law. The second regards the intrinsic logic of law since it means how law uses the three main dimensions of time: present, past and future.

In general, modern thinking has considered the occurrence of law in time by using two main narratives. In the next sub-section, we see how this dichotomy is more apparent than real.

The first narrative, attributable to Hobbes (2017) and Bentham (1970), denies any value to time. For them the law is an 'artificial product'; it arises over time, but is intrinsically immutable once it is in force (see Bretone, 1989, pp. 10-16 and the contrast he remarks between Hobbes and Aristotle over time in law). Time determines the existence of law without consequences for its way of existing; it can act on the law only from the outside. It has been said that law does not have a 'life' and thus an evolution of its own (for the Italian doctrine, see Romano, 1947).

The timelessness of law is also a postulate of legal positivism. This idea connects with the claim of a parliamentary monopoly of law-making, the principle of legal certainty, and the judge's duty to be, as Montesquieu argued, the 'bouche de la Loi'. Of course, this position presupposes a profound separation between public and private life and, on a deeper level, a social homogeneity, as was the case in the bourgeois social milieu of the 19th century. This conception meant progress as a process that develops within an immobile horizon defined by a constant normative will, guaranteeing the conditions for the spontaneous reconstruction of social equilibrium. In the early 20th century, Kelsen postulated the irrelevance of time as an element of the law (Kelsen, 1967). This famous Austrian scholar affirmed that time is external to law and cannot produce any consequence automatically. Valid statute laws are perpetual, but their endurance can encounter limits either because of the legislature's will that limits them or because the behaviours or the things that statutes regulate become impossible. Even Luhmann (1985) argues that the "'good law" now no longer seems to be located in the past, but in an open future'.

In contrast with the positivistic idea is a 'post-positivistic' narrative that presupposes the relevance of time in law. (We can find an echo of the classic theory of von Savigny, 1979 that argues for the 'validating force' of time for law.) This idea is not an anti-positivistic theory, but more narrowly a refusal of legal formalism and its corollaries, such as the isolation of law from morality and the claim that legal rules can be legitimized only by their formal validity. This theory holds that time intercepts law in the act of interpreting legal texts. The starting assumption is that law is the product of an act of interpretation that creates norms from textual propositions. Each legal text, such as a legislative statute, is not introduced into the flow of history as a finite product, ready for use immediately. Only by applying its provisions to a concrete case does a legislative statute receive a completed meaning in a specific context.

The second, big issue regards in what way time is in law, i.e. how legal relationships live in time, or, to express it differently, how temporalities are used to command human relationships and, hence, the temporal dimensions of legal enforcement.

Generally, scholars - both positivistic and post-positivistic - tend to consider the legal representation of time as an 'objective' business. These authors consider time in law as an objective element, as Newtonian physics and then Bergsonian 
philosophy claim. Bergson and Pogson (1910) distinguishes temp from durée. The former refers to the objective nature of time (quantitative homogeneity), meaning time as an external object made up of numbers (seconds, minutes, hours, days, etc.) to which law refers (Witte, 2019). Whereas, durée refers to the internal temporal structure of a legal procedure, meaning the development of legal relationships.

Indeed, the temporal landmark of law is always a specific time segment represented by a portion of the time continuity line. In law, time and duration are coincident concepts because the fulcrum of law is the concept of legal relationship, which is never without continuity and development (Cotta, 1981).

Present time dominates the issue of time in law. One can understand the past as a province of the present, which is the source for predicting the future. St. Augustine formulated an unsurpassed interpretation of the present time in connection with the past and the future. He condenses the three dimensions of time to three temporal modalities: 'the present of things past, the present of things present, and the present of things future' (Augustine, 2019). Drawing on Augustine's thought, the dominance of the present in law emerges at three levels: enforcement, drafting of all texts and legal argumentation.

As Engisch (1955) affirmed, from the moment of entry into force until the moment in which its validity ceases, a body of laws 'is neither old nor young, but is simply existing'. Only interpretation can get older and be substituted by a new one. Repeal affects the temporal effects of legal norms and creates a time segment of law enforcement, as the expression tempus regit actum or factum shows. This brocardo helps the interpreter decide the enforcement of a legal provision on a legal relationship. Law, indeed, is forbidden to modify the course of time having only the power to qualify a legal relationship following time. Even when a proposition operates retroactively, the reality remains the same, but present rules extend to past acts or facts. Indeed, the effectiveness of a piece of legislation could be 'retroactive', 'immediate' and 'delayed'. This distinction derives from the Tractatus Novissimus de Tempore Legali of Joannis Caroli Antonelli, where a distinction between tempus continuum and tempus utile also appears.

\subsection{Law Is Contingent and Temporally-Spatialized}

The theoretical dichotomy between law in time and time in law is only apparent when looked at more closely. This insight is particularly evident if we consider the necessary temporal coherence of a legal system as decisive for interpretation, law enforcement and legal certainty. Indeed, a legal system possesses the temporal structure of history itself since it displays its effectiveness in accordance with its meaning, when and to the extent to which it proceeds together with time (Husserl, 1955). Every legal norm belonging to a specific legal system always has its existential roots in one particular historical situation. The moment of birth of a legal clause is not a 'today' or a specific instant in history. It is more broadly the concrete historical situation that motivates and guides lawmakers' actions.

Thus, no legal system - even in a specific territory - is valid for all time. It is always a system valid for one particular (contingent) community, and its rules are binding on the members the community recognizes itself in it. As with other his- 
torical phenomena, legal systems also have a beginning and an end. The maximum life span of a legal system corresponds to the length of time measuring the existence of its community of reference. While we do not know the precise duration of a legal system, we do know it is contingent.

In general, a legal system represents that kind of partial system connected to the whole order of a community (other partial systems are religion, moral, customs and the economy). To be 'partial' means being incomplete. Indeed, an element of incompleteness is inherent in every legal norm. Unlike other human products (such as art and other tools), legal norms, once they are introduced, are dependent on the behaviour of people acting in accordance with them. Once introduced, legal norms enter historical time. Thus, time does not stand still, and norms proceed with it. They are propositions devoted to steering behaviour or to organizing reality and do not possess a fixed meaning corresponding to the one that they had initially at the moment of their creation. Interpretations of a legal norm exist in the present, even when the present sense is interpreted with reference to the legal system, as we can see in contemporary constitutions. Gianformaggio (1997) masterfully expressed this idea of connecting the evolution of constitutions as a social pact with the conservation of a national community.

We cannot forget that even when a legal norm comes into existence with a creative act, it has a pre-history: i.e., how the necessity for law-making emerged in the community. To understand the legislature or government's activity, we have to refer to the ideal situation where the reason for willing originated.

It is worth considering an essential element. The legislature or the government will always have to play a role, even if limited, in fixing the meaning of the legal norms that are parts of legislative acts. However, the legislature or executive's will cannot have the last word in matters relating to the interpretation of legislation. The final word belongs to the interpreter, the judge (both in the common and civil law traditions) (Malt, 1995; Summers \& MacCormick, 1991).

Consequently, in interpreting a legal provision, one will undoubtedly have to go back to the historical context in which the act of creation (e.g. a session of the parliament) established that legal norm, the statute or regulation to which it belongs and its pre-history. However, this is only the starting point of the interpretation process (Sunstein, 1989). The further task will have to consist of severing the law from its bond with the historical moment in which it arose, and ideally stretching it to the present (interpretation). Only in this way can a living connection be established with today's reality and problems. As Bell (1998) affirmed, the 'validity of the contemporary norms of the legal system presupposes that they were not simply enacted in the past, but that they continue to have institutional support from the values which justify the legal system'.

Thus, time is not purely external to the life of legislation. In the same way, each legal norm proceeds with time, since it is produced by interpretation in terms of the substantive values that justify the current state of affairs. The intrinsic law of a legal system is a functional transformation towards fairer and more equitable legal norms. 


\subsection{Time, Change and Legal Relationships}

A legal system cannot remain static since the law is subject to continuous transformation (French, 2001; Friedman, 1975; Ranchordás \& Roznai, 2020). Issues of law undergo change, grow and perish in historical time. No legal system lives forever, and neither do constitutions. Despite the continued existence of the political community that once recognized itself in it but which has now detached itself from it, a legal system can undergo a total collapse either due to war or for other reasons. However, 'the contingency of law is not pure facticity', but the effect of the validity, certainty and correctness implied in every legal system (Alexy, 1995; Pfersmann, 2013).

From a mechanical point of view, the single legal norm undergoes a dismantling of its existence when it is no longer in force. This can happen either when a subsequent act of legislation puts an end to the presence of the previous one or because of a 'temporary' law (when the time limit placed on a legal norm becomes a reality, it loses its validity - Ginsburg et al., 2014).

The French Enlightenment postulated that laws speak as if they had validity for all time. Yet, also when a rule does not have a legally established end, its existence has a time limit, even if it cannot be uniquely determined in advance.

By establishing specific legal norms, the legislature takes an advance provision regarding the future affected by those norms. Law-making anticipates a stretch of future events from the point of view of a given present. Trespassing into the future (as the legislature does) means projecting forward in time assessments and stances regarding the present. The essential structural transformations of social reality, which are the reasons for the legislature's activity, establish the foundation for its work. However, the long arms of the legislature, which extend into the future, do have a finite length because they create unfinished propositions that need the work of other people (interpreters) to become effective.

In principle, legislation-making proceeds by ideally planning certain typical life situations and endowing them with specific legal effects. In so doing, the legislature regularly connects with things of social reality that pre-exist law.

One of the oldest categories of legal entities comprises 'legal relationships', such as contract, testament, crime, freedom of expression and other fundamental rights. Subjective rights, legal privileges, obligations, powers etc. arise from legal relationships (Nedelsky, 2011). Every legal relationship can be coupled with a specific experience of law and a particular issue of time, even if they all belong to the same temporal, historical structure as the legal system of which they are apart.

As opposed to the above-mentioned legal entities, there are legal sources (and norms) that law limits temporally. An excellent example of such a legal entity is the 'executive order'. From a temporal perspective, the application of executive orders has a beginning and an end. Their application exists between two time extremities, both defined by the law that created them in an objective, measured time (whereas historical time is filled with human contents and, generally speaking, historical events).

The existence of a legal entity between two poles of objective time can have very different meanings: on the one hand, there are things in which the attainment of the end of their existence means their interruption and a cessation of their va- 
lidity; on the other hand, we have legal entities whose meaning depends on the fulfilment of an end (Simoncini, 2003): their presence is undoubtedly between two temporal poles, but their essence pushes and moves them towards the end of their existence. Both kinds of things exist in objective time, which delimits them. But their internal temporal structure, which is essential to them, is different. The issuer uses this legal instrument to establish (or re-establish) a situation that the legal system has designated as compliant with the law. Some executive orders are a 'function of an end'. To achieve a concrete, practical end, an order of this kind has a final meaning. The legal device complies with its definition when used for the purpose that corresponds to the same idea as decided in the legal norm of recognition. In Italy, scholars explained this using the basic features of the principio di legalità (Carlassare, 1966; Cheli, 1967).

\section{Time Dimensions and Law-Making}

Three original forms of time compose the legal temporal experience: past, present and future. Therefore, we could speak of a tripartite structure of the knowledge of legal time (this should be considered differently from the dimension of objective time considered by physics and natural sciences). For a legal entity to enter into humankind's domain, one of these three temporal forms is necessary. Citing Bergson (1944), some legal scholars call this conclusion a 'temporal spatialization of law' (Merleau-Ponty, 1976).

Among the three forms of time, the present - as St. Augustine argued - possesses absolute primacy (Bagolini, 1970; Heidegger, 1962). If we say that something belongs to the past, we mean that a man or a woman of the present can experience it in the present only in the temporal form of the past (the past always has a meaning in the present time). In principle, there is not much difference as regards the things belonging to the future time. However, every image of the future represents a realm of the possible, seen from the past and present.

As a matter of fact, none of the three dimensions is independent of the others, since they continuously pass into each other. Past time continues to fill up the present time, and the latter is a future horizon. Simultaneously, in every person's life, the past, present and future come together in a single large space of experience. Put differently, the understanding of time in law implies inter-temporality (French, 2001; von Benda-Beckmann, 2014) and the understanding that no human experience is limited to just one of the three modes of time.

If we consider the act of law-making, for example, we find that although it is oriented towards the future, its dependency on the present and the past is not imaginary. Indeed, it is impossible to see the temporal experiences of the legislature, government and judiciary as belonging correspondingly to the future, present and past, as Husserl (1955) argued. Even if this theory hit the mark for its coherence and simplicity, it is impossible to match the separation of power with the dimensions of time only because they are composed of three equal elements. Yet, Husserl's thesis helps insofar as it allows us to understand the temporal issues of law-making, their practical connection with time and the variable dominance of time dimensions in the history of a legal system. This analysis shows that no phase 
of historical time can be without the other, but one temporal step could prevail over the others in the experience of law-making.

While the idea of attributing to the legislature, the executive and the judiciary a specific form of time (Husserl, 1955) seems naïve and oversimplified, the temporal perspective applied to the separation of power could explain the degree of influence that parliaments, governments and judges exercise over the spirit of a community in a precise moment. We could call it genius saeculi or Zeitgeist, the trend of thought and feeling in a specific time (Krause, 2019). In this respect, as Calamandrei (1955) alleged, the history of human civilization has learned alternatively from periods of slow evolution, which may seem to be stagnant, to periods of precipitous social transformation, which may seem uncertain.

Nowadays, as Hussler affirms, the dominance of the present marks the acquisition for the executive of more space and the reduction of the parliament's role as future anticipator and planner, celebrating its transformation into a 'supervisor'. Here, the threat of decline and risk prevails over the idea of definitiveness (eternity) intrinsic in legislation (and judicial decisions). However, the prevalence of the present does not mean the paralysis of law-making, but an abundance of it and its transformation into administrative-like law-making (Calabresi, 1982). Thus, legal norms often take on the nature of directives and commands, so the boundaries between general rules of conduct and orders blur.

The executive looks ahead but does not look far, because it is short-sighted. If we analyse this phenomenon from the point of view of social science, the dominance of the present in decision making satisfies the mass, which lives only in the present (Canetti, 1981). The people, contrariwise, live in the consciousness of its past.

\section{The Influence of 'Acceleration' on Law-Making and the Effects for Legisla- tion}

It is common sense to affirm that the technological transformation has given contemporary men and women more time (Borgmann, 1987; Hassan, 2009; Koselleck, 2009). This condition derives broadly from the philosophical, scientific and technical advancements of the last two centuries (Kern, 2003; Rosa, 2013; Virilio, 1977), but it has accelerated enormously over the past thirty years (French, 2001). Thus, the relationship between time and law must be reconsidered in light of the social and economic consequences of the last twenty years' scientific and technological progress. New ways of communicating and networking have abolished spatial distances, at the same time reducing the delay in the transmission of signals, due to the process of 'immediacy'.

Ferrarese (2001) observed two effects of globalization on time: 'simultaneity' and 'virtuality'. However, she warned of simplification as regards the acceleration of time, affirming that a more profound transformation affects the relevance of present, past and future. For Ferrarese, indeed, a hypertrophic presence of the present marks the shift in time. The present time passes from being a short and perishable parenthesis enclosed between the past and the future to become a temporal dimension, which is increasingly omnivorous and centre stage. Both history 
and future time lose their autonomous meaning; they tend to become functional accessories of the present: 'more and more they are conceived and reinvented according to the present's needs' (Ferrarese, 2001). Technological obsolescence and disruption are significant signs of this process and examples for other 'devices' like those of the law. Consequently, a problem of obsolescence affects legislation, whose duration decreases as reality accelerates its pace.

First, one of the main symbols of state power, statute law, seems to be undergoing a substantial loss of importance, if not a real decline. Other legal 'protagonists' dominate the prevalence of the present that invades our time, intercepting the need for flexibility that is typical of globalization and technological disruption. The downfall of statute law symbolizes the declining role of the institutions that most responded to the future and, conversely, a rapid and sudden fortune for the institutions that have the most incredible capacity to consider the present's needs. Hence, the responsibility of time is shifting from parliament to government, namely from parliamentary to governmental legislation and regulation.

By analysing the recent evolution of Italian legislation from a constitutional point of view, the transformation of statute laws into legal devices similar to administrative measures should be noted. Statute law has today a precarious existence being either repealed or changed within limited periods (Longo, 2017). This kind of legislation is far from the idea of codification we inherited from the Enlightenment, which was intended to last. Whereas, today's legislation is destined to be in force for a limited time (between two temporal poles, as mentioned earlier) and with the need to fulfil a specific goal. While it is flexible and useful in times of emergency and governs globalization, this legislation usually lacks effectiveness and jeopardies legal relationships, trust and legal calculability (Irti, 2014).

In the post-COVID-19 time, the acceleration of legislation yields new effects, such as the need to preserve bare life (Agamben, 2020). COVID-19 has been considered the "biggest threat in living memory to health and well-being, social welfare, and the global economy' (Kickbusch et al., 2020). Today, to recover our economies and build resiliency, we are borrowing money from future generations (Next Generation EU), promising them, first and foremost, to reinvent the world and then solve the primary issue of surviving (health and environment are the top priorities). Legislation too has inherited the purpose of human survival and developed it into 'time-shaped' legislation.

In our 'survivor time' (Überlebenszeit), it is impossible to socially distance emergency legislation from ordinary legislation since the two types of legislation are blended at the outset, both deriving from government's law-making. Even if emergency legislation is limited and time-bound, the normalization of an emergency justifies the use of fast-track or urgent procedures over the time of their application. For parliaments and citizens, it is too challenging to demand 'socially distant legislation' (Cormacain, 2020). This condition leads us to have another variety of legal temporality: the 'survivor time' of catastrophic periods.

'Survivor time' appears as an evolution of 'aleatory time', which Ost and van de Kerchove (1993) point out as an evolution of the relationship between time and law and which other scholars called 'multiphrenic' or 'saturated' time (French, 2001). For Ost and van deKerchove, when legislation continuously changes in the 
modern welfare state, the law ultimately produces new forms of temporality, leading us to forms of 'radicalized change'. An inevitable corollary of aleatory time is normative inflation (von Benda-Beckmann, 2014; Wistrich, 2011); the 'speed of circulation' of rules accelerates to the point of causing them to lose their hold on the social body: legislation jostles, collides, is repealed or modified even before being applied. In aleatory time, we talk about forecasting, foresight and planning. However, the opening up of the future that is thus emerging is linked to its radical unpredictability; since everything now seems possible, nothing is guaranteed, especially since there is a lack of a widely mobilizing discourse that could outline some coherent perspective for the future.

In 'surviving' time, the future is very open, but also uncertain. However, while in the first stage of this era, risk essentially signified 'a way of calculating unpredictable consequences', today we face 'manufactured uncertainties' in which 'those who endanger the public well-being and those charged with its protection may well be identical' (Beck, 2006).

While legislatures are part of the risk environment and increasingly make decisions in uncertainty, legislation becomes precarious. In many realms of social and economic life, the future seems to be experienced as less instead of more predictable. As Giddens (2006) predicted, people manage to deal with this risk by developing a 'protective cocoon of basic trust [that] blocks off most otherwise potentially disturbing happenings which impinge on the individual's life circumstances'.

The way in which legislation incorporates risk affects the time horizons of the institution and the balance between parliament and government. Legislatures have to definitively surrender to the executives. Procedures and sources of law are highly deformalized and temporary. Today, the only lifeline we can easily clutch onto is technology. Human consciousness lives in 'technological continuous time'. Indeed, in a post-COVID-19 world, trust in the redeeming force of science and technology is the only way to survive. Technology reorders distances, overcomes spatial and temporal barriers and links distant populations more rapidly and intensely (French, 2001). Besides, faith in technology and science guarantees the possibility of surviving in the pandemic thanks to medicine and the pharma industry.

Though legislation becomes highly precarious, various legal techniques are now attempting to remedy this precariousness somewhat. The best is undoubtedly that of 'temporary laws', which from the outset provide that legislation will only be in force for a limited period, being self-repealing after an unavoidable delay (Fagan, 2013). Since the future is open and uncertain, practices of 'experimentation' dominate the survivor time. Even legislation definitively assumes another trait because its legitimation depends on the aptitude to achieve specific objectives and the capacity to be effective. We know from French scholars that in the last thirty years, the law has become more devoted to governing the present; conversely, evaluation and experimentation techniques dominate the process of law-making (Chevallier, 1996; Crouzatier-Durand, 2003). The evaluative approach is characterized by introducing permanent correction and adjustment devices of legislation based on experience and observation (Mamontoff, 1998; Van den Bos \& Hulst, 2016). 


\subsection{Temporary Legislation, Experimentation and Effectiveness}

The hallmarks of current legislation lie in the consolidation of new law-making procedures and the worsening of the executives' dominance over parliaments. The secret of this operation rests on the authority of present time over the future and the past. In the last thirty years, governments have gained the ability to become massive producers of 'temporary legislation', often using experimental law equipment. This section looks at the existing experimental features and practices of law, focusing on effectivity in legislation.

Although the theoretical issues of temporary legislation are only rarely in the mind of continental law scholars, the legal instruments related to this field of inquiry have been vividly present in the experience of civil law countries for a long time (Ranchordás \& Roznai, 2020). The importance of temporary and experimental legislation is mainly a problem related to 'effectiveness'. With interim measures in legislation, government or parliament could overcome its aversion to real change, namely, social, economic, technological and scientific advances (Ranchordás, 2014b).

Hence, the substitution of government legislation for parliament's laws could be ascribed to the gap ineffectiveness created by the difficulty for the latter of coping with change. As the Italian case shows, governments are much 'swifter' in issuing temporary legislation than permanent legislation. The executives focus and orient themselves towards solving real and contingent problems proposing temporal legislation that solves emergency issues, or de facto creates 'experiments': measures ready to be adapted to new circumstances, even in a time close to that of its coming into force, notwithstanding the uncertainty produced (Gersen, 2007; Popelier, 2008). To describe this situation and then take a look at the problems it raises for the effectiveness of law, it is necessary to start with a consideration of the practice of temporary legislation.

The immense number of social and economic relations in contemporary society requires a new tempo for legislation and accelerated procedures. Law-making in a post-accelerated society has become synonymous with immediate and obsolescent responses because legislation - similar to other resources - is subject to deterioration or precarization after use. The increase in law-demand is at odds with parliaments' slow response and, in some cases, with their inability to react (Longo, 2017).

However, by dint of overproduction, legislation loses value (inflation as Eng, 2002 discusses), negatively reflecting on the work of government in two ways: on the one hand, once generated, legislation 'escapes from the hands of its producer', which has relatively little understanding of how it can be updated; on the other, introducing legal norms means, at the same time, creating the need to update it. As some scholars have heatedly argued, today's legislation is made to be consumed as a commodity and traded as a currency, rather than being a product destined to endure (Rose, 1984). It is here that temporary legislation becomes vital for a legal system.

Even before COVID-19, an overwhelming portion of legislation enacted by the Italian Government, for example, was termed 'temporary', because it contained either clauses limiting the duration of their validity or articles setting up experi- 
ments for a limited time (Albanesi, 2020). In Italian legislation, namely in budget laws (legge di bilancio), law-decrees (decreto-legge) and delegated laws (decreto legislative), it is common to have informal clauses of experimentation that set a date or a period for implementing a measure, others setting up a derogation from existing rules or standards, with or without an ex-post evaluation. These practices are widespread in labour, social security, taxation, public administration innovation, etc. In many cases, the articles setting up the experimentation establish a parliamentary evaluation but do not usually link the latter to the deadline of the experiment (unlike other jurisdictions, Italy lacks a transparent institutional model for implementing experimental legislation Bar-Siman-Tov, 2017). These practices are set up for political purposes (Lupo, 2019), usually concealing the necessity to reach consensus among parties in the majority over a legislative proposal, as Albanesi (2020) clearly pointed out.

Yet, Italian law-making practice also teaches another negative approach to temporary legislation when dealing with law-decrees by extending the temporal validity of provisions with sunset clauses. Every year in Italy, since the early 2000s, governments, with limited debate and evaluation from legislators, have been enacting law-decrees to reauthorize provisions originally destined to sunset (Longo, 2017). These provisions demonstrate that the mere provision of future scrutiny is not the certification of effectiveness.

The difficulty in crafting temporary and experimental laws is not surprising. Whereas scholars mark a clear distinction between temporary legislation and experimental legislation (Ranchordás, 2013, 2014b), the legal practice often mixes up the two terms. Indeed, experimental legislation belongs to the family of temporary law and is temporary by definition because it intends to test a new regulatory framework for a certain period, to analyse the effects that this will produce (Ranchordás, 2014a). At the end of the experimental period, based on the results, the legislature will decide either to make the experimental regulation definitive, modify it or abandon it.

For experimental legislation to be drawn up, the legislature or the government must include a law deadline (duration clause). Duration clauses are established $a b$ initio in the legislative act itself. An evaluation of the effects produced through modalities that may be variable is provided. Any final confirmation of the discipline is subject to the adoption of a different law, which may make any changes deemed necessary in the light of the experience undergone.

French scholars (Chevallier, 1996) employ two dichotomies to distinguish the uses of experimentation in law: internal or external and global or partial. The first distinction depends on whether legislation concerns only the reorganization of one or more state services or whether it produces effects on external subjects. Regarding the second, the experimentation can be global when legislatures decide to apply new legislation throughout the national territory but for a limited period, drawing lessons from experience and then deciding on the fate of the discipline tested; it can be partial when new legislation is experimented in a specific geographical area (experimentation in space) or on certain portions of the population (sectoral experimentation), before generalizing it to the whole territory or to the 
population itself, always subject to modifications deemed appropriate (Chevallier, 1993; Crouzatier-Durand, 2003).

The use of the 'experimental approach' in the legal domain can raise perplexity if we consider the structural difference that separates the law from the other sciences: the legal rule is traditionally defined as an act of will that is indeed normative; it necessitates either acting or not in a specific situation (for the Italian literature see Crisafulli, 1976). Whereas, experimental legislation adds a 'knowledge path' to the normativity dynamic, aiming to verify a hypothesis through experience and reconstruct the links between the observed phenomena (cause and effect).

The synthesis between these two approaches gives rise to an undoubtedly peculiar reality: an act that, despite having the nature of a legal norm, producing obligations and being capable of affecting the subjective positions of third parties, is called on to play also a cognitive role, as a provisional and preparatory act for a subsequent decision (Bar-Siman-Tov \& Harari-Heit, 2020). Thus, the effectiveness of legal norms serves to generate a successive change, which allows us to investigate how experimentally certain variables interact (Terré, 1980).

This type of legislation is widespread in several European states. However, the generality, abstractness and temporal continuity of the legal rule appear to be sacrificed entirely, in a type of intervention with many elements in common with the procedure typical of administrative action. Experimental legislation seems to compromise the legal geometry imagined by modern constitutional scholars who defined the law, in accordance with the dogma of the Enlightenment, as an 'expression of the general will' (see the formula contained in the famous chapter VI, book XI, of Rousseau's 'Social Contract'). In this cultural tradition, the law certainly did not constitute the outcome of a path based on experience, but rather a 'construction of the spirit', as a direct emanation of reason (Montesquieu, 1867, book first, chapt. first).

\subsection{From a Geometric Idea of Legislation to a New Idea of Law-Making}

The new tempo of legislation that we have described above induced the abandonment of the Enlightenment rationality of law and opened up a slow process of precarization in the law-making activity. Far from being a mere 'crisis of law', this process symbolized the advent of new constitutionalism after World War II and the necessity of creating the basis for social and economic progress in the aftermath of the 'catastrophe'.

Indeed, this process - as mentioned in the previous section - started after the first world conflict, but it has become mature only in contemporary constitutions (Forsthoff, 1964). This mutation embodied a different way of understanding the relationship between time and law and forced legislatures to find alternative ways to pursue sudden social changes (Friedman, 1975). Contemporary constitutions registered the increasing 'demand' for legislation coming from society and the economy, which had made it possible to deploy hitherto unpredictable spaces for state action (as Waldron, 1999 affirms 'every day another demand emerges for new legislation to deal with some difficulty or to reorganize some aspect of social affairs'). In this situation, the law becomes the social system that, more than any 
other, could prepare itself to assume importance in the orientation of action in modern society, as expressed in the sociological analysis of Luhmann (2009).

Thus, the so-called crisis of the legislation, far from being dissipated either in the criticism of the quality of the regulatory texts or as the impairment of the liberal ideology of the 19th century (Burdeau, 1939; Ripert, 1949), coincided with the abandonment of these criteria of rationality, which reached their peak in the 19th-century codifications.

Sectoral legislation, overproduction of laws and temporary laws, continuously changed to keep up with reality, but the principles of certainty and security were not forgotten. Nonetheless, their enforcement was dynamically saddled with different methods (Popelier, 2008): on the one hand was the activity of the executive that could swiftly reflect changes in the economy and society and the ability to risk; on the other, the interpretative work of the judiciary that could fill the gap created by the obsolescence of legislation.

Some scholars contextualized these transformations in the evolution of the state role, particularly in the advent of a different kind of 'state' (Bartole, 2008). Some contemporary constitutions embodied the idea of giving everyone an opportunity, smoothing those differences that produce inequalities, helping people in need, as is set out in Article 3 of the Italian and the Spanish Constitutions (Cassese, 2017). Within this framework, legislatures become the forefront of the state's new targets, and even the scope of law-making changes. As a currency, laws must express principles or clauses endowed with intrinsic rationality destined to last over time. The legislation is justified in its suitability to achieve the short- or long-term objectives pursued from time to time by the legislature for the immediate realization of its intervention programmes.

In the new constitutional state, law-making has thus become an instrument of action put at the service of the state for the implementation of its public policies and the achievement of specific economic and social results (Kaufmann, 2012); with a somewhat effective formula, it has been said that it expresses 'measures' and no longer 'rules'. However, the exploitation of the law leads to its corruption and its transformation into an 'instrument of government'. Scholars have assimilated public regulators to private enterprise, considering law as a 'management technique' or an 'operational technique'.

In this context, there was no longer any justification for legal norms in themselves as the bearers of self-legitimizing rationality, but only in a different goal that transcends and justifies them, as the realization of a broader, but contingent, programme. Social pluralism, the contingency of situations and the particularity of the regulatory hypotheses are forced to modulate the strategy of regulation on targeted interventions and its spatial and temporal scope.

Governments use the law as a means to develop a new society in the present. In a plural and multipolar system, legal norms are an element of a programme dictated by a party or a collation of parties (Burdeau, 1963). This evolution has had various implications for the reconstruction of the legislative phenomenon. In the first place, the law has taken on many of the features typical of the administrative act in a system in which the separation between the legislator's roles and those of the administrator has become increasingly blurred. Indeed, while Ripert (1949) 
has included among the manifestations of the crisis of the legislative power the so-called lois réglementaires, in Italy, Mortati (1968) devoted an entire volume to the study of the administrative laws (leggi provvedimento).

Furthermore, the rationality criteria of legislative intervention and the parameters for its evaluation undergo a change in scope. The 'validity' of law, in fact, no longer depended merely on its suitability to make individual behaviours conform in a sense desired by it, but on its ability to achieve the objectives pursued, that is, on its 'effectiveness' (De Benedetto, 2018; Rangeon, 1989). As a finalized activity, with effectiveness, the quality of the law can be appreciated in the light of the comparison between the results achieved and those set out in it, to verify the suitability of the means used for the ends (Mousmouti, 2019). Therefore, this criterion has been placed side by side with the more traditional effectivity category, which refers to an objective fact, i.e. law enforcement.

In the making and in the factual reality in which the law is enforced, it is necessary to arrive at a prediction of the outcome that is as reliable as possible and identify the effects produced while comparing them with those expected (Mousmouti, 2019).

Therefore, the development of experimental legislation must be placed in the context briefly reconstructed so far, which represents the most urgent attempt to rationalize legislative production through the aid of methods borrowed from the hard sciences. However, this empirical turn in legislation does not mean contradicting the counterfactual validity of the law, even if the lack of evidence affects legal validity (Luhmann, 1985).

What has been learned from this transformation has been beneficial during the pandemic. These tools allowed governments to develop policy responses rapidly under severe pressure, without exploiting constitutional 'state of exception' clauses. Administrations worldwide have responded to the crisis by employing a wide range of measures, including fast-track legislation, formal and informal secondary legislation and non-legislative changes as well as new procedures with experts' committees using data for decision making (OECD, 2020). Most of these measures contain expiry dates and are intended to be temporary in nature.

Today, even parliaments must confront this new way of law-making, reassessing their role in accordance with the duty to oversee and assess the executives' decision making (Griglio, 2020). Drawing from the lesson learned during these months of the pandemic, we could prospectively find a new framework for the separation of powers in the post-COVID-19 world.

\section{Concluding Remarks: The Post-COVID-19 Scenario}

I have argued that the exceptional circumstances brought about by the COVID-19 pandemic have definitively accelerated the tempo of law-making, giving governments the solitary sceptre for solving state problems, such as the economy, business, healthcare, school, welfare, etc. The overestimation of governments in the pandemic results from many factors, such as the acceleration produced by the ongoing digital disruption, the ability of administrations to manage risk and create 'science rooms' (Morvillo, 2020). All these factors have helped European countries 
to establish a definitive change in law-making and, on account of the pandemic, take a different approach to temporary and experimental legislation in the legal system in a different way.

However, the COVID-19 legislation raises many questions, such as the limits and the likely 'normalization' of the emergency, the appropriateness and the time limit of these powers (Petrov, 2020). To overcome these deficiencies, temporary legislation tools are unquestionably useful mechanisms for guaranteeing democratic values in law-making. In order to achieve the goal, the introduction of parliamentary scrutiny, ex-post assessment and judicial oversight must be integrated with the need for effective and immediately enforceable legislation. Any response to the pandemic must have a 'sound legal basis' and be justified in terms of 'timing' and complying with evidence. Law-making is today more a process to manage continuously than an activity to perform instantly.

As described in this article, COVID-19 opens up a new scenario for the relationship between time and law introducing the narrative of the 'survivor'. Parliaments and governments must, therefore, assume this policy target as one of the pillars of a post-COVID-19 society, as the European Union intergovernmental agreement on the 'Next Generation EU' demonstrates. In order to hone our ability to respond to future crises, we need to repair and transform our economies and societies today because while surviving we must be aware that 'we will inhabit a different world' (Harari, 2020).

\section{References}

Agamben, G. (2020). Biosicurezza e politica. Retrieved from www.quodlibet.it/giorgioagamben-biosicurezza.

Albanesi, E. (2020). Temporary legislation as a mechanism for reaching consensus. A critical analysis in the absence of ex post evaluation. In S. Ranchordas \& Y. Roznai (Eds.), Time, law, and change: An interdisciplinary study (pp. 191-208). New York: Hart.

Alemanno, A. (2020). Taming COVID-19 by regulation: An opportunity for self-reflection. European Journal of Risk Regulation, 11(2), 187-194.

Alexy, R. (1995). Law, discourse and time. In J. Bjarup \& M. Blegvad (Ed.), Time, law and society (pp. 23-40). Stuttgart: Steiner.

Augustine, O. H. S. (2019). Confessions (New edition, translated by Thomas Williams ed.). Indianapolis: Hackett Publishing Company.

Bagolini, L. (1970). Significati della parola «tempo» in alcuni discorsi giuridici. Rivista Trimestrale di Diritto e Procedura Civile, 22(2), 333-368.

Bar-Siman-Tov, I. (2017). Temporary legislation, better regulation, and experimentalist governance: An empirical study. Regulation \& Governance. doi:10.1111/rego.12148.

Bar-Siman-Tov, I. \& Harari-Heit, G. (2020). The legisprudential and political functions of temporary legislation. In S. Ranchordas \& Y. Roznai (Eds.), Time, law, and change: An interdisciplinary study. New York: Hart.

Barber, N. W. (2018). The principles of constitutionalism. Oxford: Oxford University Press.

Bartole, S. (2008). Stato (forme di). In Enc. dir. (Vol. Annali II). Milano: Giuffrè.

Beck, U. (2006). Risk society revisited: theory, politics and research. In J. F. Cosgrave (Ed.), The sociology of risk and gambling reader. London: Routledge.

Bell, J. (1998). Interpreting statutes over time. In M. Van Hoecke \& F. Ost (Eds.), Time and Law (Le temps et le droit) (pp. 451-469). Bruxelles: Bruylant. 
Bentham, J. (1970). Of laws in general (H. L. A. Hart Ed.). London: The Athlone Press.

Bergson, H. (1910). Time and free will, an essay on the immediate data of consciousness. London and New York: Sonnenschein.

Bergson, H. (1944). Essai sur les données immédiates de la conscience (43. ed.). Paris: Presses Universitaires de France.

Borges, J. L. (1960). Otras inquisiciones. Buenos Aires: Emecé.

Borgmann, A. (1987). Technology and the character of contemporary life: A philosophical inquiry. Chicago: University of Chicago Press.

Bretone, M. (1989). Le norme e il tempo. Fra tradizione classica e coscienza moderna. Materiali per una st. della cult. giur., XIX(1), 7-26.

Burdeau, G. (1939). Essai sur l'évolution de la notion de loi en droit français. Archives de philosophie du droit et de sociologie juridique, 9(1-2), 7-55.

Burdeau, G. (1963). Le déclin de la loi. Archives de philosophie du droit, 8, 35-41.

Calabresi, G. (1982). A common law for the age of statutes. Cambridge, MA and London: Harvard University Press.

Calamandrei, P. (1955). La funzione della giurisprudenza nel tempo presente. Bari-Roma: Laterza.

Canetti, E. (1981). Crowds and power. New York: Continuum.

Carlassare, L. (1966). Regolamenti dell'esecutivo e principio di legalità. Padova: Cedam.

Cassese, S. (2017). L'eguaglianza sostanziale nella Costituzione: genesi di una norma rivoluzionaria. Le Carte e la Storia, 23(1), 5-13.

Cheli, E. (1967). Potere regolamentare e struttura costituzionale. Milano: A. Giuffrè.

Chevallier, J. (1993). Les lois expérimentales: le cas français. In C.-A. Morand (Ed.), Evaluation législative et lois expérimentales (pp. 119- 152). Aix-en-Provence: Presse universitaire d'Aix-Marseille.

Chevallier, J. (1996). Les lois expérimentales: le cas français. In D. T. Bourcier \& C. Thomasset (Eds.), L'écriture du droit (pp. 167-203). Paris: Éditions Diderot.

Cormacain, R. (2020). Keeping Covid-19 emergency legislation socially distant from ordinary legislation: Principles for the structure of emergency legislation. The Theory and Practice of Legislation, 8(3), 1-21.

Cotta, S. (1981). Diritto e tempo. Linee di una interpretazione fenomenologica. Rivista Internazionale di Filosofia del Diritto, 34(1), 119-128.

Crisafulli, V. (1976). Lezioni di diritto costituzionale. Le fonti normative (4th ed.). Padova: Cedam.

Crouzatier-Durand, F. (2003). Réflexions sur le concept d'expérimentation législative. Revue française de droit constitutionnel, 56(3), 675-695.

De Benedetto, M. (2018). Effective law from a regulatory and administrative law perspective. European Journal of Risk Regulation, 9(3), 391-415.

Eng, S. (2002). Legislative inflation and the quality of law. In L. Wintgens (Ed.), Legisprudence: A new theoretical approach to legislation. Oxford: Hart Publishing.

Engisch, K. (1955). Vom Weltbild des Juristen. Frankfurt am Main: C. Winter.

Fagan, F. (2013). After the sunset: The residual effect of temporary legislation. European Journal of Law and Economics, 36(1), 209-226.

Ferrarese, M. R. (2001). Il diritto al presente: globalizzazione e tempo delle istituzioni. Bologna: Il mulino.

Forsthoff, E. (1964). Rechtsstaat im Wandel: verfassungsrechtliche Abhandlungen 1950-1964. Stuttgart: Kohlhammer.

French, R. R. (2001). Time in the Law. University of Colorado Law Review, 72(3) 663-748.

Friedman, L. M. (1975). The legal system: A social science perspective. New York: Russell Sage Foundation.

Frosini, V. (1999). Temporalità e diritto. Rivista di Diritto Civile, XLV(3), 431-437. 
Gersen, J. E. (2007). Temporary legislation. The University of Chicago Law Review, 74, 247298.

Gianformaggio, L. (1997). Tempo della costituzione, tempo della consolidazione. Politica del diritto, 28(4), 527-552.

Giddens, A. (2006). Fate, risk and security. In J. F. Cosgrave (Ed.), The sociology of risk and gambling reader. London: Routledge.

Ginsburg, T., Masur, J. S. \& McAdams, R. H. (2014). Libertarian paternalism, path dependence, and temporary law. The University of Chicago Law Review, 81(1), 291-359.

Ginsburg, T. \& Versteeg, M. (2020). Binding the unbound executive: checks and balances in times of pandemic. Virginia Public Law and Legal Theory Research Paper No. 2020-52.

Griglio, E. (2020). Parliamentary oversight under the Covid-19 emergency: striving against executive dominance. The Theory and Practice of Legislation, 8(1-2), 1-22.

Harari, Y. N. (2020, March 20). The world after Coronavirus. Financial Times.

Hassan, R. (2009). Empires of speed: Time and the acceleration of politics and society. Leiden: Brill.

Heidegger, M. (1962). Being and time. London: SCM Press.

Hobbes, T. (2017). Leviathan (new edition ed.). UK: Penguin Classics.

Husserl, G. (1955). Recht und Zeit: Funf rechtsphilosophische Essays. Frankfurt am Main: Klostermann.

Irti, N. (2014). Calcolabilità weberiana e crisi della fattispecie. Rivista di Diritto Civile, 60(5), 987-991.

Kaufmann, F.-X. (2012). European foundations of the welfare state. New York and Oxford: Berghahn books.

Kelsen, H. (1967). Pure theory of law. Berkeley: University of California Press.

Kern, S. (2003). The culture of time and space, 1880-1918: With a new preface. Boston: Harvard University Press.

Kickbusch, I., Leung, G. M., Bhutta, Z. A., Matsoso, M. P., Ihekweazu, C. \& Abbasi, K. (2020). Covid-19: How a virus is turning the world upside down. British Medical Journal, 369, m1336. doi:10.1136/bmj.m1336.

Koselleck, R. (2009). Is there an acceleration of history. In H. Rosa \& W. E. Scheuerman (Eds.), High-speed society. Social acceleration, power and modernity (pp. 113-134). University Park, PA: Pennsylvania State University Press.

Krause, M. (2019). What is Zeitgeist? Examining period-specific cultural patterns. Poetics, 76, 101352. doi:10.1016/j.poetic.2019.02.003.

Longo, E. (2017). La legge precaria. Le trasformazioni della funzione legislativa nell'età dell'accelerazione. Torino: Giappichelli.

Loughlin, M. (2019). The contemporary crisis of constitutional democracy. Oxford Journal of Legal Studies, 39(2), 435-454.

Luhmann, N. (1985). A sociological theory of law. London: Routledge.

Luhmann, N. (2009). Law as a social system. Oxford: OUP.

Lupo, N. (2019). «Populismo legislativo?»: continuità e discontinuità nelle tendenze della legislazione italiana. Ragion Pratica.

Malt, G.-F. (1995). Dynamic interpretation, spatial and temporal aspects in interpretation. In J. Bjarup \& M. Blegvad (Eds.), Time, law and society. Stuttgart: Steiner.

Mamontoff, C. (1998). Réflexions sur l'expérimentation du droit. Revue du droit public et de la science politique en France et a l'etranger, 20(2), 351-372.

Mengoni, L. (1998). Diritto e tempo. Jus 58(3), 635-645.

Merleau-Ponty, M. (1976). Phénoménologie de la perception. Paris: Gallimard.

Meßerschmidt, K. (2020). COVID-19 Legislation in the light of the precautionary principle. The Theory and Practice of Legislation, 8(3), 267-292. doi:10.1080/20508840.2020.1783 627.

Montesquieu. (1867). Esprit des lois. Paris: Libr. de F. Didot Frères. 
Mortati, C. (1968). Le leggi provvedimento. Milano: Giuffrè.

Morvillo, M. (2020). I just can't get enough (of experts): The numbers of COVID-19 and the need for a European approach to testing. European Journal of Risk Regulation, 11(2), 366374.

Mousmouti, M. (2019). Designing effective legislation. London: Edward Elgar Publishing.

Nedelsky, J. (2011). Law's relations: A relational theory of self, autonomy, and law. New York: Oxford University Press.

Nousiainen, K. (1995). Time of law - time of experience. In K. B. Bjarup, M. (Ed.), Time, law and society (pp. 23-40). Stuttgart: Steiner.

OECD. (2020). Regulatory quality and COVID-19: The use of regulatory management tools in a time of crisis. Paris. Retrieved from www.oecd.org/coronavirus/policy-responses/ regulatory-quality-and-covid-19-the-use-of-regulatory-management-tools-in-a-timeof-crisis-b876d5dc/

Ost, F. \& van de Kerchove, M. (1993). Pluralisme temporel et changement. Les jeux du droit. In Nouveaux itinéraires en droit. Hommage à François Rigaux (pp. 387-411). Bruxelles: Bruylant.

Petrov, J. (2020). The COVID-19 emergency in the age of executive aggrandizement: what role for legislative and judicial checks? The Theory and Practice of Legislation, 8(1-2), 7192.

Pfersmann, O. (2013). Il quadro strutturale della temporalità degli ordinamenti normativi giuridici. In AA.VV (Eds), Diritto intertemporale e rapporti civilistici. Napoli: ESI.

Pistor, K. (2020). Law in the time of COVID-19. In C. L. School (Ed.). Retrieved from https:// scholarship.law.columbia.edu/books/240.

Popelier, P. (2008). Five paradoxes on legal certainty and the lawmaker. Legisprudence, 2(1), 47-66.

Popelier, P. (2020). COVID-19 Legislation in Belgium at the crossroads of a political and a health crisis. The Theory and Practice of Legislation, 8(1-2), 131-153. doi:10.1080/20508 840.2020.1771884.

Posner, E. A. (2017). Introduction. In F. Fagan \& S. Levmore (Eds.), The timing of lawmaking. London: Edward Elgar Publishing.

Ranchordás, S. (2013). The whys and woes of experimental legislation. The Theory and Practice of Legislation, 1(3), 415-440.

Ranchordás, S. (2014a). Constitutional sunsets and experimental legislation. A comparative perspective. Cheltenham: Edward Elgar.

Ranchordás, S. (2014b). Sunset clauses and experimental regulations: Blessing or curse for legal certainty? Statute Law Review, 36(1), 28-45. doi:10.1093/slr/hmu002.

Ranchordás, S. \& Roznai, Y. (2020). Time matters: How time shapes law and regulation. In S. Ranchordas \& Y. Roznai (Eds.), Time, law, and change: an interdisciplinary study. New York: Hart.

Rangeon, F. (1989). Réflexions sur l'effectivité du droit. In Les usages sociaux du droit (pp. 126). Paris: Presses Universitaires de France.

Ripert, G. (1949). Le déclin du droit: études sur la législation contemporaine. Paris: Libr. générale de droit et de jurisprudence.

Romano, S. (1947). Interpretazione evolutiva. In Frammenti di un dizionario giuridico. Milano: Giuffrè.

Rosa, H. (2013). Social acceleration: A new theory of modernity. New York: Columbia University Press.

Rose, R. (1984). Understanding big government: The programme approach. London: Sage.

Scheuerman, W. E. (2002). Motorized legislation? Statutes in an age of speed. ARSP: Archiv für Rechts-und Sozialphilosophie/Archives for Philosophy of Law and Social Philosophy, 88, 379-397. 
Schmitt, C. (1950). Die Lage der europäischen Rechtswissenschaft. Tübingen: Internationaler Universitäts.

Simoncini, A. (2003). Le funzioni del decreto-legge. La decretazione d'urgenza dopo la sentenza n. 360/1996 della Corte Costituzionale. Milano: Giuffrè.

Summers, R. S. \& MacCormick, N. (1991). Interpreting statutes: A comparative study. Aldershot: Dartmouth.

Sunstein, C. R. (1989). Interpreting statutes in the regulatory state. Harvard Law Review, 405-508.

Terré, F. (1980). La «crise de la loi». Archives de philosophie du droit, 25, 27.

Teubner, G. (2012). Constitutional fragments: Societal constitutionalism and globalization. New York: Oxford University Press.

Tsebelis, G. (2009). Agenda setting and executive dominance in politics. In S. Ganghof, C. Hönnige \& C. Stecker (Eds.), Parlamente, Agendasetzung und Vetospieler (pp. 13-24). Cham: Springer.

Van den Bos, K. \& Hulst, L. (2016). On experiments in empirical legal research. Law and Method, 2016(1), 1-18.

Virilio, P. (1977). Vitesse et politique: essai de dromologie. Paris: Galilée.

von Benda-Beckmann, K. (2014). Trust and the temporalities of law. The Journal of Legal Pluralism and Unofficial Law, 46(1), 1-17.

von Savigny, F. K. (1979). System of the modern Roman law. Westport, CT: Hyperion Press.

Waldron, J. (1999). The dignity of legislation. Cambridge: Cambridge University Press.

Weinrib, L. (2006). The postwar paradigm and American exceptionalism. In S. Choudhry (Ed.), The migration of constitutional ideas (pp. 83-113). Cambridge: Cambridge University Press.

Wintgens, L. (2002). Legisprudence: A new theoretical approach to legislation. Oxford: Hart Publishing.

Wistrich, A. J. (2011). The evolving temporality of lawmaking. Connecticut Law Review, 44, 737.

Witte, A. (2019). The international regulation and governance of time. Max Planck Yearbook of United Nations Law Online, 22(1), 394-426. doi:10.1163/18757413_022001016. 